\title{
Rusland som ensom magt
}

\section{Vibeke Sperling}

\section{Fremragende bog af russisk analytiker påviser øget afstand mellem Rusland og Vesten, bedst som alle troede, at Obama havde gjort kløften mindre}

Lilia Shevtsova: Lonely Power: Why Russia Has Failed to Become the West and the West is Weary of Russia. Carnegie Endowment, Washington, $361 \mathrm{~s}$.

$\mathrm{Nu}$ troede mange lige, at alt kunne blive bedre i Rusland og imellem Rusland og omverdenen med den tilsyneladende mere liberale Dmitrij Medvedev ved roret og hans amerikanske kollega Barack Obamas 'reset' af relationerne til Rusland.

Men den russiske analytiker ved Carnegie Center, Lilja Sjevtsova (nordisk transskription), der pendler mellem Moskva og Washington, fortæller os, at Medvedevs fortsættelse af Vladimir Putins udenrigspolitik kun har øget Ruslands 'adskillelse fra Vesten'.

Bogen om den 'ensomme magt' kunne dårligt komme på et bedre tidspunkt end under en naturkatastrofe i Rusland, der afslørede et regime, der ikke kunne reagere effektivt. Regimet kan ikke varetage bor- gernes interesser, fordi det er for centraliseret og for modsætningsfyldt - på en og samme tid samt primært koncentreret om at bevare egen magt, ifølge Sjevtsova.

"Systemet reddes i dag af kun en kendsgerning - manglen på en troværdig opposition. Men det faktum, at social vrede og frustration vokser hurtigere end den politiske proces kan absorbere, øger dagligt faren for degradering og demoralisering", skriver Sjevtsova, der leverer vægtige analyser til at forstå regimet, som blev skabt på Sovjetunionens ruiner.

Sjevtsova hudfletter ikke kun Ruslands vej til et nyt autoritært system men også Vestens bidrag til, at den mulige udvikling til markedsøkonomi og demokrati løb af sporet efter Sovjetunionens sammenbrud i 1991. Sjevtsova viser, at Vesten forspildte den mest oplagte chance for at hjælpe Rusland ind på reformsporet. Det var lige efter kommunismens fald.

Vesten har påvirket Ruslands 


\section{LITTERATUR}

udenrigspolitik ved flere lejligheder. Men "hvad angår den interne transformation, var Vestens eneste chance for at påvirke retningen for Ruslands udvikling i 1991-92, da landet stadig ikke havde besluttet sin vej. Men Vesten foretrak ikke at blande sig i Ruslands indre anliggender i den periode. Da det i 1993 begyndte at hjælpe Rusland, havde toget forladt stationen".

Det blev ifølge Sjevtsova hurtigt klart, at "den russiske elite desværre ikke var parat til at opgive magtmonopolet og lære at fungere i et politisk miljø med intern konkurrence". Det gjaldt også liberale, der kom til tops under Jeltsin. "Liberale og demokrater uden intentioner om at opgive magten - en sand russisk opfindelse".

\section{Personaliseret regime}

Selv om forfatteren mener, at det gik helt galt med Vladimir Putin, fremhæver hun, at kursen blev udstukket med den nye forfatning under Boris Jeltsin, som skabte det 'personaliserede' regime, som Putin siden perfektionerede.

EU's kurs var et eksempel på, "hvordan Vesten hjalp den russiske elite med at genetablere den traditionelle stat". Til indvendinger om tilsyneladende demokratiske fremskridt fra Kreml skriver Sjevtsova, at “de kun var eksempler på Moskvas evne til at imitere europæiske principper".
Ruslands elite havde "ingen intentioner om at tilpasse russisk lovgivning og praksis til EU's normer, men denne mangel på entusiasme for sande reformer havde ingen indflydelse på den hjælp, som Europa gav til Rusland. Tværtimod var karakteren, formen og modtagerne af hjælp defineret i konsultation med den russiske regering".

Hjælpen blev således dirigeret hen, hvor russiske embedsmænd ønskede. "Situationen tilfredsstillede både russiske bureaukrater og deres europæiske kolleger, men havde ringe indflydelse på reformprocessen".

Sjevtsova afdækker, at mange vestlige ledere først var bange for et sovjetisk sammenbrud og derfor støttede den sidste sovjetleder, Mikhail Gorbatjov, men ikke nok til at forhindre sammenbruddet. Efter stor skepsis over for Jeltsin blev han kæledæggen og siden hans udvalgte efterfølger Putin. Og efter stigende bevidsthed om Putins tilbagerulning af demokrati, blev vestlige forventninger overført til dennes udvalgte, Medvedev.

I dag står vi med en russisk elite, der er styret af 'tilbageskuende logik' over for omverdenen. Medvedev bekræftede det allerede i juni 2008, da han underskrev en ny udenrigspolitisk doktrin, hvori det hedder: "Reaktionen på perspektivet om at miste Vestens historiske monopol på globaliseringen er især udtrykt i princippet om at 'inddæmme’ Rusland, herunder forsøg på en 
selektiv omgang med historien, først og fremmest om Anden Verdenskrig og efterkrigstiden".

Vi så således ifølge Sjevtsova den nye præsident skrue udenrigspolitikken tilbage til tesen, at "den vestlige civilisation går tilbage", på linje med sovjettidens opfattelse af kapitalismens uundgåelige nederlag.

Konflikterne med især Polen, Ukraine og de baltiske lande om fortolkningen af historien viste, "at vi bør lægge særligt mærke til regimets bestræbelser for tilbagevenden til fortiden og for at bestemme, hvordan den skal fortolkes".

Ruslands forsvar for det sovjetiske perspektiv på Anden Verdenskrig fortæller ifølge Sjevtsova meget om den russiske elite: "Det fortæller os, at Rusland ikke er parat til at vende bladet væk fra den totalitære fortid. Det vil heller ikke tillade andre lande at gøre det".

Nabolande får at vide, at det er en fælles fortid, som det kræver russisk tilladelse at fortolke. Når Rusland ikke vil bearbejde fortiden sammen med andre tidligere sovjetstater, ser Sjevtsova det som en enorm 'mistet mulighed'.

\section{Illusioner om Medvedev}

"Alle forventede mere liberale vinde, når Medvedev havde overtaget præsidentskabet. Dementeringen af de forventninger viser, at sovjetisk geopolitik har overlevet: I realiteten er Ruslands adskillelse fra Vesten øget”.
Det blev bekræftet af Ruslands invasion i Georgien i august 2008, som Vesten de facto har accepteret til fordel for ny harmoni med Moskva.

Barack Obamas 'reset' af USA's forhold til Vesten har "mildt sagt ikke udvirket mirakler", men "hjælper tværtimod den russiske elite med at undgå forandringer".

Regimets liv afhænger af "bevarelse af det personfikserede styre og dets geopolitiske ambitioner vil gøre alle diplomatiske 'resets' midlertidige".

Det russiske regime har fortsat brug for en 'ydre fjende'. Konsekvensen er, at "russisk udenrigspolitik ikke har opnået et eneste af målene på sin dagsorden - hverken globalt eller regionalt lederskab endsige national modernisering".

Sjevtsova argumenterer for, at regimet før eller siden tvinges til at erkende, at det 'nuværende pseudo-system' har udtømt sine muligheder: "En stat, som tilfredsstiller snævre interesser, mens den lader som om den tilfredsstiller nationale interesser, eller som forhindrer samfundsmæssig transformation, men hverken har ressourcerne til at lukke resten af verden ude eller undertrykke samfundet”.

Rusland står nu med en elite, der tror, at den kan modernisere uden at liberalisere.

\section{Hvad Vesten ikke bør}

Sjevtsova har gode forslag til, hvad 


\section{LITTERATUR}

Vesten bør gøre og ikke mindst ikke bør gøre: "Rusland ville sandelig se anderledes på Vesten, hvis vestlige politikere holdt op med at arbejde for Kreml".

Vesten må ændre både sin stil og retorik i omgangen med Rusland. "At skifte til business-like samarbejde uden forsøg på at skabe personlig kemi med russiske ledere, ville udgøre et reelt bidrag til Ruslands transformation. Som det er nu, ser vestlige ledere stadig 'personlig kemi' med det russiske tandem som hemmeligheden bag succes i Rusland".

Vesten må genfinde den rolle, som det tidligere spillede i det russiske samfunds øjne som et attraktivt alternativ til den russiske petrostat.

Den russiske elite er parat til at fortsætte konversationerne med Vesten i det uendelige, "fordi den ser det som et middel til at styrke status quo, men den russiske offentlighed skal ikke lide under Vestens forsøg på at civilisere den russiske elite".

Sjevtsova fremhæver, at vi er endt i en situation, hvor Vesten end ikke holder Rusland fast på det, som Rusland har skrevet under på. Sådan er det med Georgien, og sådan har det været med meget andet, siden Rusland blev optaget i Europarådet. Først blev optagelsen forsinket af Ruslands krig i Tjetjenien. Og så lød argumentet, at man netop bedst kunne påvirke Rusland, hvis det kom ind i varmen.
"Ved at blive medlem af Europarådet erklærede Rusland sig enigt i, at dets hjemlige anliggender ikke kun er dets private sag”. Men alligevel har Ruslands holdning, at Vesten ikke skal blande sig i dets indre anliggender, vundet gang på gang.

"Hvis vestlige ledere er bange for at irritere Rusland, kunne de i det mindste undlade at gøre ting, der kan tolkes som åben støtte til det russiske autoritære system".

Blandt de ting, som Sjevtsova mener, at Vesten bør gøre, er mere hjælp til demokratisering af Ruslands nære udland, de øvrige tidligere sovjetrepublikker: "At skabe et stabilt og demokratisk system rundt om Rusland vil være en afgørende faktor for dets fornyelse. Det er også det, som den russiske elite frygter meget mere end direkte vestlig indflydelse på det russiske samfund. Derfor kræver Kreml så stædigt retten til 'en sfære af privilegerede interesser' i nabolande; Kreml ønsker dem som en cordon sanitaire, der skal beskytte Rusland imod vestlig indflydelse. Derfor vil succes for medlemmer af Det Østlige Partnerskab også være stimuli for russiske reformer".

\section{Menneskeretsdomstolen}

Sjevtsova ser en del tegn på, at almindelige russere reagerer, men flere meningsmålinger har vist, at det store flertal ikke har illusioner om, at de kan påvirke magten.

Den store stigning i antallet af rus- 
sere, som rejser sager imod deres land ved Den Europæiske Menneskeretsdomstol, ser Sjevtsova som udtryk for, at de tror på et retssamfund, men erkender, at det ikke eksisterer i Rusland: "De tror tydeligvis også på, at Europa både har ret og pligt til at beskytte dem imod deres stat".

Reformeringen af Rusland er primært russernes sag, fremhæver Sjevtsova, men understreger, at Vesten kan og bør påvirke eliten: "Hvor hurtigt den russiske elite indser som mange russere allerede gør - at deres system ødelægger Rusland afhænger af kollektive bestræbelser fra Vesten".

Det russiske regime styres ikke af en formuleret ideologi bortset fra drømmen om status som supermagt og imperium. Regimet legitimerer sig med påstanden om, at Rusland nok er demokratisk men en helt unik form på grund af landets unikke historie og kultur.

Sjevtsova citerer en russisk analytiker for konstateringen: "Rusland er ikke en unik civilisation, men et land, der sidder fast i civilisatorisk usikkerhed".

Eliten vil genetablere imperiet og supermagten, men har ikke ressourcerne til det, og store dele af eliten deler i realiteten heller ikke ønsket om det: "Men, som det er nu, plager disse fantomer nationen, dens folk og udenrigspolitikken, understøttet af officiel retorik og militaristiske symboler".
Betyder alt dette, "at Vesten ikke kan regne med samarbejde med Rusland, før landet er transformeret?”. Sjevtsova svarer selv på sit spørgsmål: "Slet ikke. Der vil blive samarbejdet om visse sager, som tilfældet var med Sovjetunionen. Men håb ikke for meget på, at det vil være konstruktivt og bæredygtigt. Det vil ikke hjælpe med at ændre Rusland".

Det er en bog spækket med både øjenåbnende facts og dybdeborende analyser. Den er også fyldt med citater af vestlige Ruslandskendere, som Sjevtsova går i dialog med i bogen. Men hun beklager meget, at der bliver stadig større afstand imellem russiske kritikere som hende selv og vestlige kendere af russiske forhold, der mener, at russiske liberale er for kritiske.

Bogen er meget anbefalelsesværdig, en sand debatbog, hvor Sjevtsova ofte optræder som sin egen djævelens advokat. Den er spændende som en politisk krimi og let tilgængelig, da dens korte, velkomponerede afsnit ikke kræver specialviden om Rusland. Og forskeren og kommentatoren Lilja Sjevtsova ved, hvad hun har med at gøre efter flere tidligere bøger om Jeltsins og Putins regimer.

Vibeke Sperling er udlandsmedarbejder ved Politiken og redaktør af Udenrigs. 